\title{
Associations between Depression, Anxiety, Hostility and Fighting Spirit among Cancer Patients in a Cancer Center in Korea
}

\author{
Joohyung Kim, Dr. P.H., M.S., M.P.A. ${ }^{1}$, Jae-Kyung Roh, M.D., Ph.D. ${ }^{2}$, Jeoung-Soon Yoon, R.N. ${ }^{3}$, \\ Suk-Jeong Lee, R.N. ${ }^{4}$ and Dong-Yeon Lee, Ph.D. ${ }^{4}$
}

${ }^{1}$ Nursing Policy Research Institute, Yonsei University College of Nursing, Seoul; ${ }^{2}$ Department of Internal Medicine, Yonsei University College of Medicine, Seoul; ${ }^{3}$ Yonsei Cancer Center, Seoul; ${ }^{4}$ Yonsei University College of Nursing, Seoul, Korea

Purpose: The aim of this study was to examine the associations between depression, anxiety, hostility and fighting spirit among patients with stomach, colorectal or breast cancer.

Materials and Methods: 223 patients, diagnosed as with stomach, colorectal or breast cancer, undergoing chemotherapy or follow up care, were the subjects of the study. The study design was cross-sectional at the time of the survey. The degrees of depression, anxiety and hostility of the patients were assessed by the SCL-90-R scores, and the fighting spirit was measured by the Mental Adjustment to Cancer (MAC) scale score.

Results: The scores of anxiety and hostility of the pati-

\section{서 론}

지난 10년간(1990 2000) 우리나라에서 뇌혈관 질환, 사 고, 심장질환, 간질환에 의한 사망은 감소한 반면, 사망원인 1위인 암은 인구 10만명당 1990년 110.4명에서 2000년 122.1 명으로 사망률이 약 $11.7 \%$ 나 증가하였다(1). 외국의 경우에는 암발생률과 사망률의 지속적인 증가로 인해(2) 암 치료에 있어 다양한 방법적 접근을 시도하고 있으며, 최근 에는 의학적 치료의 보조적 방법으로 정신사회적인 중재를 치료와 함께 병행하고 있다.

암은 진단과 함께 우울, 불안, 적대감 등의 부정적인 정신 건강상태를 나타낸다. 특히 암 진단 직후에는 그 상태가 악

Correspondence: Joohyung Kim, Nursing Policy Research Institute, Yonsei University College of Nursing, C.P.O. Box 8044, Seoul 120-752, Korea. (Tel) 02-361-8144, (Fax) 02-392-5440, (E-mail) hspirit333@yumc.yonsei.ac.kr

Received March 13, 2003, Accepted August 27, 2003

This research was supported by Korea Research Foundation Grant (KRF-2001-050-0026). ents at younger age were higher than those at older age $(p<0.01)$. The patients with metastasis were more depressed than those without it $(p<0.01)$. There was a negative association between depression and fighting spirit $(p<$ 0.001).

Conclusion: The study showed the more depressed cancer patients had lower fighting spirit score, which was known to be one of the most active psychosocial contributorsin adjusting to cancer and survival. (Cancer Research and Treatment 2003;35:411-418)

Key Words: Depression, Anxiety, Hostility, Fighting spirit, Cancer

화된다고 보고되고 있다(3). 하지만 연구에 따르면 의사들 은 환자들의 부정적인 정신건강 상태를 파악하고 그러한 문제를 해결하는 것에 대한 관심이 부족하다고 보고되고 있다(4). 암 환자에게서 가장 흔하게 나타나는 부정적인 정 신 건강 상태는 불안과 우울로서, 불안과 우울이 환자에게 서 나타나는 비율은 0 49\%이다(5). 우울은 암의 원발 장기 에 관계없이 암발생에 다양하게 영향을 미치는 것으로 나 타나고 있다.

암 환자의 정신건강은 암 발생 후 생존기간과 삶의 질에 도 영향을 미치는 것으로 밝혀지고 있다. 불안은 암 환자의 정신적 문제 중 두드러지는 것으로서 암의 종류별 정신건 강을 조사한 결과 14 가지 암 중 췌장암 환자가 불안과 우울 이 가장 높게 나타났고(6), 조혈 모세포 이식자 중 불안 경 향을 띠는 사람이 이식 후 생존기간이 통계적으로 유의하 게 낮게 나타났다(7). 적대감은 모든 암 환자에서 나타나는 부정적인 정신건강은 아니나 대장암 환자는 대조군에 비하 여 공격적 적대감이 유의하게 높게 나타났다(8). 우울이나 불안, 적대감 등의 부정적인 정신건강상태는 직접적으로 질병 발생과 과정에 영향을 주거나 혹은 건강에 해로운 행 
동유발이나 비적극적인 대처를 통해 질병 과정에 간접적인 영향을 주는 것으로 알려져 있다(9).

대처(Coping)란 일반적으로 스트레스를 일으키는 사건과 신체적, 정신적 적응 사이에서 중요한 중재 요인으로 여겨 지고 있다. 즉 인간의 자원을 초과하는 내적 외적 요구를 관리하기 위해 지속적으로 인지적 행위적 노력을 변화시키 는 것이라 할 수 있다(10). 암에 대한 대처 형태는 투병정신 (Fighting Spirit), 무력감(Helplessness), 불안에 사로잡힘(Anxious preoccupation), 운명론적 태도(Fatalism), 도피(Avoidance)의 다섯 가지 심리적 형태로 나타나며, 이 중 투병정 신은 암 환자의 삶의 질에 긍정적인 영향을 주는 주요한 개념으로 이해되고 있다(11).

암 환자들의 암에 대한 적절한 대처는 유방암 진단 후 5 년, 10 년, 15 년 동안의 재발을 예견하고(12), 암 환자들의 삶 의 질을 결정하는 중요한 요소의 하나(13)이며, 정신건강과 도 상관성을 보인다는 연구결과가 발표되었다(14). 적극적 인 대처 중 하나인 투병정신은 우울과 불안이 낮은 사람에 게서 높았고(15), 환자의 신체적 결과의 독립적인 예후 요 인이며, 생존기간과도 상관관계가 있다고 보고되었다(16).

정신건강과 적극적인 대처가 암 환자의 삶의 질과 생존 에 영향을 준다는 연구 결과와는 반대로 정신 건강상태와 대처가 암 환자의 삶의 질에는 영향을 미치나 생존기간과 는 관련이 없다는 연구결과도 있어서(17) 암 환자의 정신 건강과 적극적인 대처가 암의 예후와 삶의 질에 어떠한 영 향을 주는지는 향후 추가적인 연구가 진행되어야 한다고 생각 된다.

현재 외국과는 달리, 국내에서는 암 환자의 정신건강 상 태와 암에 대한 대처 실태, 정신건강상태와 대처와의 상호 관련성 등 정신사회적 중재를 위한 기초 연구가 부족한 실 정이다. 이에 본 연구에서는 국내에서 가장 유병률이 높은 위암(18)을 비롯해서 대장암과 유방암 환자를 대상으로 암 환자의 정신 건강 상태로 가장 문제시되고 있는 우울, 불안, 적대감, 그리고 대처 중에서 가장 긍정적인 형태인 투병정 신(Fighting Spirit)의 실태를 파악하고, 이들간의 관련성을 조사하여 암 환자의 정신 사회적인 중재를 위한 기초 자료 를 제시하고자 한다.

\section{대상 및 방법}

\section{1) 대상}

연세대학교 의과대학 세브란스병원에서 위암, 대장암, 유 방암으로 진단 받고 외과에서 절제 수술을 받은 환자로 2002년 2월1일부터 5월 30일 현재 항암 약물 치료를 받고 있거나, 항암 치료 후에 추후 관리 중인 223명을 연구 대상
으로 하였다.

\section{2) 방법}

일 종합병원 암센터에서 관리 받고 있는 위암, 대장암, 유 방암 환자를 대상으로 그들의 정신 건강 상태와 암에 대한 긍정적 대처 형태인 투병정신과의 관계를 파악하기 위한 서술적 조사 연구이다. 연구 절차는 먼저 암 환자의 정신사 회적 건강 상태를 평가하기 위한 설문지를 개발하였다. 그 후 암센터 외래 환자들을 치료하고 있는 주치의와 수간호 사에게 연구의 목적과 취지를 설명하고 협조를 구하였다.

2002년 3월 2일부터 5월 30일 사이에 암센터 외래에 항암 치료를 하기 위해서 방문했거나 항암 치료 후 정기 검진을 위해 외래를 방문한 환자들을 대상자로 선택하였고, 설문 지 작성이 가능한 정도의 건강 상태이면서 연구참여에 동 의한 환자에게 설문지를 작성하도록 하였다. 설문지 작성 이 끝나면 연구보조원이 2002년 6월 1일부터 1개월간 대상 자의 챠트를 검토하여 질병 관련 사항을 조사하였다.

사용한 연구 도구는 다음과 같다. 정신 건강 상태는 김광 일 등(19)이 Symptom Check List-90-Revision (SCL-90-R)을 표준화한 한국판 간이정신진단검사를 사용하였다. 이 검사 는 미국 Johns Hopkins 의과대학 정신과의 임상 심리학자 L.R. Derogatis 교수와 그의 동료들에 의해 제작된 'Symptom Checklist-90-Revision'을 우리나라에서 사용할 수 있도록 재 표준화한 자기 보고식 다차원 증상 목록 검사로 9 개의 증상 척도로 구성되어 있으며, 본 연구에서는 우울, 불안, 적대감 의 3 가지 증상척도를 사용하였다.

우울 13 문항, 불안 10 문항, 적대감 6 문항의 총 29 문항이 고, 지난 일주일 동안 경험한 증상의 정도에 따라 '전혀 없 다, 약간 있다, 웬만큼 있다, 꽤 심하다, 아주 심하다'의 5점 평정을 하게 되어 있다. 우울 증상 척도는 기분이나 감정이 저조해지고 매사에 흥미가 없어지고 의욕이 없고 절망감, 자살에 대한 생각 등 임상적으로 우울증의 증상과 일치되 는 증상들이 포함된다. 불안 증상 척도는 신경과민, 긴장, 초조, 두려움 및 불안과 관련된 신체적 증상으로 이루어졌 고, 적대감 증상 척도는 분노, 공격성, 자극과민성, 격분, 울 분 등 부정적인 정서상태를 내포하는 사고, 감정 및 행동을 반영한다. 표준화 작업 당시 검사-재검사 신뢰도는 우울 증 상 척도는 .76, 불안 증상 척도는 .77, 적대감 증상 척도는 .73 이었고, 내적 일관성은 우울척도가 .89 , 불안척도 .86 그 리고 적대감척도가 .68이었다(20). 본 연구에서 우울 증상 척도의 신뢰도 (Chronbach's alpha)는 .8737, 불안 증상 척도 의 신뢰도는 .9274, 적대감 증상 척도의 신뢰도는 .7945이다.

투병정신은 암에 대한 심리적인 대처 도구(MAC: Mental Adjust To Cancer Scale)로 측정하였다. Watson 등(12)이 개 
발한 이 도구는 영국에서 개발된 자가기술식 설문 도구로 서 투병정신(Fighting Spirit), 무력감(Helplessness), 불안에 사로잡힘(Anxious preoccupation), 운명론적 태도(Fatalism), 도피(Avoidance)의 다섯 가지 형태로 구성되어 있다.

본 연구에서는 암에 대한 심리적 대처 형태 중 가장 이로 운 반응으로 밝혀져 있는 투병정신으로 심리적 대처정도를 보았다. 미국에서 공부한 간호학 박사가 원문의 투병정신 16 문항을 한국어로 번역하고 영어로 역번역하여 대조한 후 20 명의 환자에게 사전조사를 하여 타당도를 확인한 후 사 용하였다. 이전 연구에서 투병정신 도구의 1 개월 측정-재측 정 신뢰도가 .71로 나타났고(20), 본 연구에서는 신뢰도가 .8597이었다.

투병정신은 '대상자가 진단을 도전으로 받아들이고 미래 에 대해 낙천적으로 생각하며 질병을 조절하려고 노력하 며, 명백하게 암을 정복하려는 반응을 보이는 것'을 포함하 는 것(21)으로서 각각의 대답은 '나에게 절대로 적용되지 않는다, '나에게 적용되지 않는다', '나에게 적용된다', '나 에게 매우 적용된다'의 4점 척도로 점수가 높을수록 투병정 신이 높아 암을 극복하려는 의지가 높음을 나타낸다.

Table 1. General characteristics of patients

\begin{tabular}{llcl}
\hline Characteristics & & N $(\%)^{*}$ \\
\hline Sex & Male & $89(39.9)$ \\
& Female & $134(60.1)$ \\
Age & $20 \sim 29$ & $4(1.8)$ \\
& $30 \sim 39$ & $34(15.2)$ \\
& $40 \sim 49$ & $55(24.7)$ \\
& $50 \sim 59$ & $57(25.6)$ \\
& $60 \sim 69$ & $62(27.8)$ \\
& $70 \geq$ & $11(4.9)$ \\
Education level & Below high school & $133(59.4)$ \\
& College graduate & $64(28.6)$ \\
& Above graduate school & $16(7.1)$ \\
Marital status & Married & $187(87.8)$ \\
& Seperation by death & $10(4.7)$ \\
& Divorced/seperated & $8(3.6)$ \\
& Unmarried & $8(3.8)$ \\
Present occupation & No & $27(12.1)$ \\
& Yes & $55(24.6)$ \\
(10.000 won) & $100 \sim 199$ & $56(25.0)$ \\
& $200 \sim 299$ & $63(28.1)$ \\
& $300 \sim$ & $149(66.5)$ \\
& & $61(27.2)$ \\
\hline
\end{tabular}

*excluded missing value

\section{3) 통계 분석}

대상자의 일반적 특성은 실수와 백분율로 구하였고, 대 상자의 정신건강 상태와 투병 정신은 평균과 표준 편차를 구하였다. 정신건강, 투병정신과 일반적 특성과의 차이는 t-test와 ANOVA를 실시했다. 정신건강과 투병정신 도구의 신뢰도를 Cronbach's alpha로 보았다.

우울은 총점을 $25 \%$ 씩 퍼센트화하고 불안, 적대감은 $50 \%$ 씩 퍼센트화하여 투병정신과의 관계를 회귀분석으로 파악 하였다.

\section{결 과}

\section{1) 대상자의 일반적인 특성}

본 연구 대상자는 남자 89 명(39.9\%), 여자 134명(60.1\%)으 로 20대 4명(1.8\%), 30대가 (15.2\%), 40대 55명(24.7\%), 50대 57 명 $(25.6 \%), 60$ 대 62 명(27.8\%) 그리고 70세 이상은 11 명 (4.9\%)으로 총 223 명이었다.

Table 2. Characteristics related to disease status of patients

\begin{tabular}{|c|c|c|}
\hline Characteristics & & $\mathrm{N}(\%)$ \\
\hline \multirow[t]{4}{*}{ Diagnosis } & Stomach $\mathrm{Ca}$ & $62(27.7)$ \\
\hline & Colorectal $\mathrm{Ca}$ & 89 (39.9) \\
\hline & Breast $\mathrm{Ca}$ & 79 (35.3) \\
\hline & Complex & $12(5.8)$ \\
\hline \multirow[t]{4}{*}{ Stage } & 1 & $9(4.0)$ \\
\hline & 2 & $69(30.8)$ \\
\hline & 3 & $99(44.2)$ \\
\hline & 4 & $30(13.4)$ \\
\hline \multirow[t]{2}{*}{ Metastasis or recurrance } & No & $158(70.9)$ \\
\hline & Yes & $53(23.7)$ \\
\hline \multirow[t]{2}{*}{ Present status } & Follow up & $30(15.5)$ \\
\hline & $\begin{array}{l}\text { Chemo or radio } \\
\text { therapy }\end{array}$ & $181(81.2)$ \\
\hline \multirow[t]{3}{*}{ Radio therapy } & No & $122(54.5)$ \\
\hline & Present doing & $64(28.6)$ \\
\hline & Past done & $21(9.4)$ \\
\hline \multirow[t]{6}{*}{ Duration of Dx } & $\sim 12$ month & $132(59.2)$ \\
\hline & $13 \sim 24$ month & $34(15.2)$ \\
\hline & $25 \sim 36$ month & $15(6.7)$ \\
\hline & $37 \sim 48$ month & $9(4.0)$ \\
\hline & $49 \sim 60$ month & $5(2.2)$ \\
\hline & 61 month $\sim$ & $16(7.2)$ \\
\hline
\end{tabular}




\section{Cancer Research and Treatment 2003;35(5)}

교육수준은 고등학교 졸업 이하의 경우가 133 명(59.4\%), 대학교 졸업자 64명(28.6\%), 대학원 졸업자 16명(7.1\%)이었 다. 현재 직업이 있는 사람이 61 명 $(27.2 \%)$ 이고 없는 사람이 149 명 $(66.5 \%)$ 으로 나타났다(Table 1).

\section{2) 대상자의 질병 관련 특성}

위암 환자 62명(27.7\%), 대장암 환자 79명(35.3\%), 유방암
환자 70명(31.3\%)이고 재발이나 전이로 여러 장기에 암을 가지고 있는 환자가 12 명 $(5.8 \%)$ 였다. 수술 당시 병기가 1 기 인 환자 9명(4.0\%), 2 기인 환자 69명(30.8\%), 3기인 환자 99 명(44.2\%), 4 기인 환자가 30 명(13.4\%)이었다. 조사 당시 재 발이 되었거나 전이가 된 환자는 53 명 $(23.7 \%)$, 재발이나 전 이가 발견되지 않은 환자는 158 명(70.9\%)이었다.

현재 상태가 항암 치료 중인 환자가 181 명(81.2\%), 항암

Table 3. Depression, anxiety, hostility and fighting spirit of patients

\begin{tabular}{|c|c|c|c|c|c|c|c|c|}
\hline \multirow{2}{*}{ Class } & \multicolumn{2}{|c|}{ Depression* } & \multicolumn{2}{|c|}{ Anxiety* } & \multicolumn{2}{|c|}{ Hostility* } & \multicolumn{2}{|c|}{ Fighting sp ${ }^{i}$ rit $^{\dagger}$} \\
\hline & Mean (SD) & $\mathrm{p}$-value & Mean (SD) & $\mathrm{p}$-value & Mean (SD) & $\mathrm{p}$-value & Mean (SD) & p-value \\
\hline \multicolumn{9}{|l|}{$\mathrm{Age}^{\ddagger}$} \\
\hline 39 or less & $1.49(0.91)$ & \multirow{3}{*}{.209} & $1.25(1.01)$ & \multirow{3}{*}{.007} & 1.08 (1.06) & \multirow{3}{*}{.001} & $3.09(0.37)$ & \multirow{3}{*}{.097} \\
\hline $40 \sim 59$ & $1.23(0.72)$ & & $0.74(0.82)$ & & $0.58(0.77)$ & & $3.06(0.37)$ & \\
\hline 60 or more & $1.32(0.67)$ & & $0.89(0.73)$ & & $0.49(0.51)$ & & $2.95(0.26)$ & \\
\hline \multicolumn{9}{|l|}{$\operatorname{Sex}^{\S}$} \\
\hline Male & $1.27(0.77)$ & \multirow{2}{*}{.496} & $0.81(0.92)$ & \multirow{2}{*}{.346} & $0.78(0.96)$ & \multirow{2}{*}{.058} & $3.04(0.38)$ & \multirow{2}{*}{.786} \\
\hline Female & $1.34(0.77)$ & & $0.93(0.80)$ & & $0.59(0.64)$ & & $3.02(0.31)$ & \\
\hline \multicolumn{9}{|l|}{ Education level $^{\ddagger}$} \\
\hline $\begin{array}{l}\text { Below } \\
\text { high school }\end{array}$ & $1.41(.74)$ & & $0.95(.89)$ & & $0.67(0.82)$ & & $2.93(0.29)$ & \\
\hline $\begin{array}{l}\text { College } \\
\text { graduate }\end{array}$ & $1.12(.72)$ & \multirow[t]{2}{*}{.058} & $0.70(.69)$ & \multirow[t]{2}{*}{.110} & $0.51(0.69)$ & \multirow[t]{2}{*}{.222} & $3.18(0.36)$ & \multirow[t]{2}{*}{.000} \\
\hline $\begin{array}{l}\text { Above } \\
\text { graduate }\end{array}$ & $1.35(.85)$ & & 1.07 (1.03) & & $0.87(0.94)$ & & $3.10(0.40)$ & \\
\hline \multicolumn{9}{|l|}{ Diagnosis $^{*}$} \\
\hline Stamach & $1.25(0.75)$ & \multirow{3}{*}{.657} & $0.91(0.91)$ & \multirow{3}{*}{.798} & $0.76(0.86)$ & \multirow{3}{*}{.333} & $3.02(0.37)$ & \multirow{3}{*}{.825} \\
\hline Colorectal & $1.34(0.74)$ & & $0.84(0.88)$ & & $0.67(0.89)$ & & $3.05(0.33)$ & \\
\hline Breast & $1.38(0.77)$ & & $0.95(0.79)$ & & $0.56(0.92)$ & & $3.02(0.33)$ & \\
\hline \multicolumn{9}{|l|}{ Stage ${ }^{\ddagger}$} \\
\hline 1 & $1.32(0.5)$ & \multirow{4}{*}{.384} & $1.08(0.54)$ & \multirow{4}{*}{.858} & $0.5(0.46)$ & & $2.96(0.16)$ & \\
\hline 2 & $1.20(0.8)$ & & $0.85(0.88)$ & & $0.72(0.98)$ & & $3.03(0.35)$ & \\
\hline 3 & $1.36(0.71)$ & & $0.90(0.89)$ & & $0.62(0.71)$ & .860 & $3.06(0.35)$ & .765 \\
\hline 4 & $1.51(0.84)$ & & $0.98(0.85)$ & & $0.69(0.71)$ & & $2.99(0.39)$ & \\
\hline Duration from & & & & & & & & \\
\hline Dx of $\mathrm{Ca}^{\ddagger}$ & & & & & & & & \\
\hline$\sim 24$ month & $1.33(0.78)$ & & $0.92(0.91)$ & & $0.73(0.87)$ & & $3.05(0.35)$ & \\
\hline $25 \sim 48$ month & $1.24(0.61)$ & .835 & $0.79(0.51)$ & .816 & $0.42(0.33)$ & .065 & $3.01(0.35)$ & .231 \\
\hline 49 month $\sim$ & $1.46(0.68)$ & & $0.88(0.74)$ & & $0.42(0.41)$ & & $2.91(0.25)$ & \\
\hline Present status ${ }^{\S}$ & & & & & & & & \\
\hline Follow up & $1.16(0.68)$ & & $0.69(0.56)$ & 065 & $0.41(0.47)$ & 009 & $3.04(0.32)$ & 890 \\
\hline Treatment & $1.36(0.76)$ & .242 & $0.93(0.89)$ & .065 & $0.71(0.84)$ & .009 & $3.03(0.34)$ & .890 \\
\hline $\begin{array}{l}\text { Metastasis or } \\
\text { recurrance }\end{array}$ & & & & & & & & \\
\hline No & $1.26(0.75)$ & 042 & $0.87(0.89)$ & 551 & $0.80(0.84)$ & 480 & $3.05(0.35)$ & 142 \\
\hline Yes & $1.52(0.72)$ & .042 & $0.96(0.76)$ & & $0.60(0.60)$ & & $2.97(0.33)$ & .142 \\
\hline
\end{tabular}

*Depress, anxiety and hostility of SCL-90-R are quantified on 0 to 4 scale, with higher scores indicating more psychological distress.

${ }^{\dagger}$ Fighting spirit of MAC are quantified on 1 to 4 scale, with higher scores indicating more positively adjustment of cancer.

${ }^{\ddagger}$ ANOVA, ${ }^{\S}$ T-test 
치료가 끝나고 추후 관리 중인 환자가 30명(13.5\%)이었다. 현재 항암 약물치료와 방사선 치료를 함께 하고 있는 환자 는 64명(28.6\%), 과거에 방사선 치료를 받았던 환자는 21명 (9.4\%), 방사선 치료를 받지 않은 환자가 122 명 $(54.5 \%)$ 이었 다. 암 진단을 받은 기간은 12 개월 이하인 환자가 가장 많아 서 132 명(59.2\%)이고 2년 이하가 34명(15.2\%), 3년 이하가 15 명(6.7\%), 4년 이하가 9명(4.0\%), 5년 이하가 5명(2.2\%), 그 이상된 환자가 16 명 $(7.2 \%)$ 이었다.

차트 검토 시에 암 환자의 이전 기록이 없거나, 명확하게 기술되지 않은 경우가 있어서 암의 병기는 17 명(7.6\%)에서, 전이여부는 13 명 $(5.8 \%)$, 현재 상태는 12 명 $(5.4 \%)$, 방사선 치 료 여부는 16 명(7.2\%), 진단 받은 기간은 12 명 $(5.4 \%)$ 을 조사 할 수 없었다(Table 2).

\section{3) 대상자의 우울, 불안, 적대감과 투병정신}

불안과 적대감은 연령에 따라 유의하게 차이가 있었다. 39 세 이하 환자의 불안 평균이 1.25 인 데 비해 $40 \sim 59$ 세의 불안 평균은 $0.74,60$ 세 이상 환자의 불안평균은 0.89 로 통 계적으로 유의하게 차이가 있었다 $(\mathrm{F}=5.093, \mathrm{p}<0.05)$. 사후 검증 결과 39 세 이하의 환자가 40 세 이상과 60 세 이상 환자 들에 비해 통계적으로 유의하게 높게 나타났다. 적대감은 39 세 이하의 환자가 1.08 인데 비해 40 59세는 $0.58,60$ 세 이상은 0.49 로 통계적으로 유의한 차이를 나타냈고 $(\mathrm{F}=5.620$, $\mathrm{p}<0.005$ ) 사후 검증 결과 39 세 이하의 환자는 40 세 이상과 60 세 이상 환자들에 비해 적대감이 높게 나타났다.

성별, 진단명별, 병기별, 암진단 받은 기간별로 우울, 불 안, 적대감은 통계적으로 유의한 차이를 보이지 않았다.

현재 항암치료 진행 중인지, 추후 관리 중인지에 따라 적 대감 평균이 0.41과 0.71로 통계적으로 유의한 차이가 있었 다 $(\mathrm{T}=3.322, \mathrm{p}<0.05)$. 전이나 재발이 있는 환자는 우울 평균 이 1.52 이고, 전이나 재발이 없는 환자는 1.35 로, 전이 여부 에 따라 우울은 통계적으로 유의한 차이를 보였다( $\mathrm{T}=-2.047$, $\mathrm{p}<0.05)$.

투병정신은 교육정도에 따라 통계적으로 유의하게 차이 가 있었다( $\mathrm{F}=11.02, \mathrm{p}<.005)$. 고졸 이하의 환자의 투병정신 의 평균은 2.93 , 대졸 환자는 3.18 , 대학원졸 환자는 3.10 으 로 사후 검증 결과 고졸 환자가 대졸이나 대학원 졸업자에 비해 낮게 나타났다(Table 3).

\section{4) 투병정신의 관련요인}

우울 점수는 투병정신 점수와 통계적으로 유의한 차이가 있었다 $(\mathrm{F}=7.811, \mathrm{p}<0.001)$. 또한 불안 점수가 $1 \%$ 에서 $50 \%$ 이하인 사람이 그 보다 높은 사람보다 투병정신의 점수가 통계적으로 유의하게 높게 나타났다 $(\mathrm{t}=2.89, \mathrm{p}<0.05)$. 적대 감 점수와 투병정신간에는 통계적으로 유의한 차이가 없었 다(Table 4).

투병정신과 관련된 요인을 회귀분석을 통하여 혼란변수

Table 4. Relationship between psychological health and fighting spirit

\begin{tabular}{|c|c|c|c|}
\hline \multirow{2}{*}{$\begin{array}{l}\text { Percent of mental } \\
\text { health score (extent } \\
\text { of total score) }\end{array}$} & \multicolumn{3}{|c|}{ Fighting spirit } \\
\hline & Total score (SD) & $\mathrm{F}$ or $\mathrm{t}$ score & p-value \\
\hline \multicolumn{4}{|l|}{ Depression } \\
\hline 1st Quartile $(0 \sim 10)$ & $51.92(5.94)$ & 7.811 & .000 \\
\hline 2nd Quartile $(11 \sim 16)$ & $48.70(5.98)$ & & \\
\hline 3rd Quartile (17～23) & $47.32(4.15)$ & & \\
\hline 4th Quartile $(24 \sim 51)$ & $46.82(4.68)$ & & \\
\hline \multicolumn{4}{|l|}{ Anxiety } \\
\hline$\sim 50 \%(0 \sim 6)$ & $50.24(5.47)$ & 2.890 & .005 \\
\hline $51 \% \sim(7 \sim 39)$ & $47.11(5.13)$ & & \\
\hline \multicolumn{4}{|l|}{ Hostility } \\
\hline$\sim 50 \%(0 \sim 2)$ & $49.29(5.47)$ & 1.618 & .108 \\
\hline $51 \% \sim(3 \sim 24)$ & $47.90(5.57)$ & & \\
\hline
\end{tabular}

Table 5. Multiple regression analysis of variables on fighting spirit

\begin{tabular}{lccccc}
\hline \multicolumn{1}{c}{ Model } & $\mathrm{B}$ & Std. error & $\mathrm{T}(\mathrm{P})$ & $\mathrm{F}(\mathrm{P})$ & $\mathrm{R}^{2}$ \\
\hline (constant) & 51.718 & 1.731 & $29.884(.000)$ & & \\
Hostility $(\sim 51 \%)$ & .407 & 1.028 & $.396(.693)$ & & \\
Depression $(26 \sim 50 \%)$ & -2.189 & 1.238 & $-1.768(.079)$ & & \\
Depression $(51 \sim 75 \%)$ & -2.904 & 1.352 & $-2.149(.033)$ & $4.921(.000)$ & .190 \\
Depression $(76 \sim 100 \%)$ & -3.442 & 1.482 & $-2.323(.022)$ & \\
Edu (college graduate) & 2.597 & .990 & $2.624(.010)$ & \\
Edu (above graduate) & 1.944 & 1.476 & $1.317(.190)$ & \\
Anxiety $(51 \% \sim)$ & -1.693 & 1.141 & $1.484(.140)$ & & \\
\hline
\end{tabular}


를 통제하고 분석하였다. 회기분석 결과 투병정신에 영향 을 주는 요인은 우울과 교육이었으며, 설명력은 $19 \%, \mathrm{~F}$ 값은 $4.921(\mathrm{p}<0.001)$ 로 회귀모형이 통계적으로 유의한 것으로 나타났다(Table 5).

우울 점수가 일사분위에 속한 환자들에 비해 이사분위에 속한 환자들의 투병정신은 2.189 만큼, 삼사분위에 속한 환 자들은 2.904만큼, 사사분위에 속한 환자들은 3.442 만큼 낮 아지나, 통계적으로 유의한 차이는 삼사분위와 사사분위에 서만 있었다 $(\mathrm{p}<0.05)$. 또한 교육정도가 고졸 환자에 비해 대졸환자들의 투병정신이 2.597만큼 통계적으로 유의하게 높아졌다 $(\mathrm{p}<0.05)$.

\section{고 찰}

본 연구에서는 암 환자의 정신건강 상태 중 우울, 불안, 적대감과 암에 대한 대처 중 가장 긍정적인 형태인 투병정 신과의 관계를 알아보았다. 본 연구 결과 암의 상태나 암의 종류는 정신건강 상태에 통계적으로 유의한 차이를 주지 않았다. 단지 전이나 재발이 된 환자가 그렇지 않은 환자보 다 우울 정도가 통계적으로 유의하게 높았고( $\mathrm{T}=-2.047, \mathrm{p}$ $<0.05)$, 현재 항암 치료 중인 환자가 추후 관리 중인 환자 보다 적대감이 유의하게 높았다 $(\mathrm{T}=-2.707, \mathrm{p}<0.001)$. 연령 별로 보았을 때 우울은 연령에 따라 차이가 없었지만 불안 과 적대감은 40 대 이전의 환자들이 그 이후의 환자들보다 유의하게 높게 나타났다 $(\mathrm{F}=5.62, \mathrm{p}<0.05, \mathrm{~F}=7.528, \mathrm{p}<$ 0.005).

투병정신은 암의 상태 및 종류, 치료 진행 상태에 따라 유의한 차이가 없었으며, 고졸 이하의 환자들이 대졸 이상 의 환자들에 비해 투병정신이 통계적으로 유의하게 낮게 나타났다 $(\mathrm{F}=10.25, \mathrm{p}<.000)$.

정신건강 상태 중 우울과 불안이 투병정신과 통계적으로 유의한 차이를 보였으며, 투병정신에 영향을 미치는 요인 은 우울, 불안, 적대감, 교육정도가 19\%를 설명하고 있었다 $\left(\mathrm{R}^{2}=190\right)$. 우울의 정도가 낮을수록 $(\mathrm{p}<.05)$, 고졸인 사람에 비해 대졸인 사람이 투병정신이 유의하게 높았다 $(\mathrm{p}<.05)$. 투병정신에 관련된 회귀분석에서는 일반적 사항에서 교육 만이 유의했으므로 교육을 통제하였고 그 외 불안, 우울, 적 대감을 독립변수로 하여 분석한 결과 $\mathrm{R}^{2}$ 가 .190으로 낮게 나왔다. $\mathrm{R}^{2}$ 수치가 낮은 것은 독립변수의 숫자가 적어서 그 런 것이고 독립변수 숫자에 비하면 낮은 편은 아니다.

SCL-90-R의 한국판 표준화 작업이 진행될 때 규준 집단 은 고등학생 남녀, 대학생 남녀 및 일반인 남녀의 6개 집단 으로 총 4,250명이 표집되었다(20). 본 연구 대상자들의 우 울, 불안, 적대감을 규준집단과 비교해 본 결과 남자 암 환
자들의 우울 평균점수는 1.26 으로 남자 규준 집단의 우울 평균 점수 0.95 보다 높게 나타났고, 불안 평균 점수는 0.81 로 규준 집단의 0.74 보다 높게 나타났다. 또한 여자 암 환자 의 우울 점수는 1.34 로서 여자 규준 집단의 우울점수 1.16 보 다 높게 나타났다. 비록 1개 대학 병원 암 환자들에 대한 결과이긴 하지만, 우리나라 일반인 규준 집단에 비해 남자 암 환자는 우울과 불안이, 여자 암 환자는 우울이 높음을 보여 주고 있어 암치료과정에 환자의 우울과 불안에 대한 이해의 필요성을 시사한다.

연구의 결과에서 전이나 재발이 발생된 환자가 그렇지 않은 환자에 비해 우울이 심하게 나타났는데 이를 통해 우 울이 전이나 재발에 영향을 미쳤는지, 전이나 재발로 인해 우울이 가중되었는지 알 수는 없지만, 우울한 정신 건강 상 태가 암이라는 질병과정과 직접 혹은 간접적인 관련이 있 을 것으로 보여진다. 본 연구에서는 기존의 연구(16)와 마 찬가지로 우울과 불안의 정도가 심하지 않은 환자가 투병 정신 정도가 높았다 $(\mathrm{p}<.001)$. 암에 대한 대처로서 가장 긍 정적인 것은 투병정신이고 부정적인 대처는 무기력과 불안 이다(21). 투병정신은 생존기간을 높인다는 결과와 재발을 줄인다는 결과(22), 암의 위험요인을 줄인다는 결과(23) 등 암치료과정에 긍정적인 영향을 준다는 많은 연구 결과가 발표되고 있다.

연구 결과에서 보듯이 불안과 우울이 낮은 환자가 투병 정신이 높았으므로 암 환자의 정신사회적 중재시에 불안, 우울을 낮추는 방법적 접근을 통해 투병정신을 높이고 암 진행과정에 긍정적인 효과를 도모할 수 있다고 생각된다. 물론 일부 연구에서는 심리적 대처와 암의 진행과는 관계 가 없다는 결과(18)도 제시되고 있어 종단적 연구나 중재 연구를 통해 보다 확실하게 적극적인 대처의 효과가 검증 되어야 하겠지만, 이미 기존의 연구에서 정신사회적인 중 재를 통해 암 환자에게 부정적인 감정을 표현하게 하고, 적 극적인 대처를 유도하여 삶의 질에 효과(24)가 입증되고 있 으므로 정신건강 상태를 증가시키고, 적극적인 대처를 유 도하게 하면 최소한 암 환자의 삶의 질이 상승되는 효과를 기대할 수 있을 것이다.

최근 뇌와 면역 체계 사이의 관계가 암의 진행을 조정하 는 것으로 알려지고 있고, 정신 건강 중재가 면역학적인 측 면에 영향을 주고 이는 감정에 영향을 주어 결국 위협에 적극적으로 대처할 수 있도록 하는 것으로 밝혀지고 있으 므로(25) 정신건강 중재를 통한 적극적인 대처를 유도함이 암 환자 관리에 매우 중요하다 할 수 있다.

본 연구의 제한점은 첫째, 단면연구이기 때문에 치료 과 정동안 다양하게 일어나는 정신건강 상태의 변이를 파악할 수 없는 점이다. SCL-90-R이 정신 건강 증상 척도이지 진단 
기준이 아니므로 우울이나 불안의 병리적인 정도를 파악할 수는 없었으나 규준 집단과 비교하는 것은 가능하였다. 정 신건강 상태의 병리적인 정도의 범위를 나타내는 대상자는 SCL-90-R을 T점수로 환산해서 70점 이상인 경우로 보고 있 으며, 본 연구에서는 우울은 19 명(9.4\%), 불안은 16 명(7.2\%), 적대감은 10 명 $(4.5 \%)$ 으로 이들은 정신과적인 정밀 진단이 필요할 수 있다.

두 번째 제한점은 조사되지 않거나 조사가 충분하지 않 은 변수가 있을 수 있다는 것이다. 정신병력의 경우 감추어 진 부분이 있을 수 있다. 하지만 객관적인 자료인 챠트 검토 상에는 우울증 약을 먹는 환자 2명을 발견하여 연구 대상에 서 제외한 것 이외에 특별한 정신병력을 발견할 수 없었다. 사회적 지지에 대한 조사가 부진한 점이 지적될 수 있다. 여러 연구에서 보고된 바와 같이 사회적 지지가 암 환자의 대처와 관련이 있는지를 조사하려 했으나, 응답률이 낮아 연구에 반영할 수 없었다. 암 환자들은 사회적지지 관련 설 문에 매우 민감하였으며 자신이 주변 사람들의 관심의 대 상인가에 대한 질문에 대하여 거부 반응을 보였다. 간호하 는 수간호사의 요청이 있었으나 많은 환자가 작성하지 않 아 추후에 환자들과의 보다 깊은 신뢰관계 형성에 관한 연 구가 필요하다고 생각한다.

세 번째 제한점은 한 기관으로부터 자료를 수집하였으므 로 우리나라 전체 암 환자를 대표할 수 없어 연구 결과를 일반화하기는 어렵다는 점이다. 향후 여러 병원들이 참가 하는 연구가 필요하다고 생각한다.

결론적으로 본 연구 결과에서는 국내 최초로 암 환자의 정신 건강 상태와 투병정신과의 관계를 알아봄으로써 암 환자의 치료과정에서 간과하기 쉬운 정신 사회적 측면을 부각시킨 점이 의미 있는 발견이라고 할 수 있다. 우울과 투병정신과의 관계는 종단적 연구를 통하여 인과관계가 좀 더 확인이 되어야 하겠지만 우울과 투병정신과의 상관성을 바탕으로 한 중재를 시도하는 것이 필요하다. 또한 투병정 신 정도에 따른 암 환자의 삶의 질과 예후에 대한 연구를 실시하여 심리적 대처의 임상적 가치를 밝히는 연구가 필 요하다고 생각한다.

\section{결 론}

위암, 대장암, 유방암 환자들의 우울과 불안은 투병정신 과 유의하게 차이가 있었고 $(\mathrm{p}<0.001)$, 우울이 심할수록 투 병정신 점수가 낮아, 암에 비적극적인 대처를 하고 있음을 알 수 있었다.

\section{REFERENCES}

1. Korea national statistics office. Annual report. 2000.

2. Tsukuma H. Incidence of cancer: Prediction in Japan up to the year 2015. Jpn J Cancer Clin 1997;38:1-10.

3. Horowitz M. Stress response syndromes and their treatment. In Handbook of stress. Theoretical and Clinical Aspects, Goldberg L, Breznitz S(eds). 1993;757-773. The free press: New York.

4. Maguire P, Booth K, Elliott C, Jones B. Helping health professionals involved in cancer care acquire key interviewing skills the impact of workshops. Eur J Cancer 1996;32:14861489.

5. Spijker AVT, Trijusburg RW, Duivenvoorden HJ. Psychological sequalae of cancer diagnosis: a meta-analytical review of 58 studies after 1980. Psychosom Med 1997;59:280-293.

6. Zabora J, BrintzenhofeSzoc K, Curbow B, Hooker C, Piantadosi S. The prevalence of psychological distress by cancer site. Psychooncology 2001;10(1):19-28.

7. Michael AA, Marianne JB, Henslee-Downey PJ. Psychosocial facters predictive of survival after allogenic bone marrow transplantation for leukemia. Psychosomatic Medicine 1994; $56: 432-439$.

8. Kavan MG, Engdahl RE, Kay S. Colon cancer: personality factors predictive of onset and stage of presentation. J Psychosom Res 1995;39(8):1031-1039.

9. Tschuschke V, Hertenstein B, Arnold R, Bunjes D, Denzinger $\mathrm{R}$, Kaechele $\mathrm{H}$. Associations between coping and survival time of adult leukemia patients receiving allogeneic bone marrow transplantation: results of a prospective study. J Psychosom Res 2001;50(5):277-285.

10. Folkman S, Lazarus RS. The relationship between coping and emotion: implication for theory and research. Soc Sci Med 1988;26(3):309-17.

11. Watson M, Greer S, Young J, Inayat Q, Burgess C, Robertson B. Development of a qustionaire measure of adjustment to cancer:the MAC scale. Psychol Med 1988;18:203-209.

12. Greer S, Morris T, Pettingale KW. Psychological response to breast cancer and 15 year outcome. Lancet 1990;335:49-50.

13. Watson M, Greer S, Rowden L, Gorman C, Robertson B, Bliss JM, Tunmore R. Relationship between emotional control, adjustment to cancer and depression and anxiety in breast cancer patients. Psychol Med 1991;21:51-57.

14. Evans DR, Thompson AB, Browne GB. Facters associated with the psychological well being of adults with acute leukemia in remission. J Clin Psychol 1993;49:153-160.

15 DiClemente RJ, Temoshok L. Psychological adjustment to having cutaneous malignant melanoma as a predicter of follow up clinical status. Psychosom Med 1985;47:81.

16. Nordin K, Glimelius B. Reactions to gastrointestinal cancervariation in mental adjustment and emotional well-being over time in patients with different prognoses. Psychooncology 1998;7(5):413-423.

17. Andrykowski MA, Brady MJ, Henslee-Downey PJ. Psychosocial facters of survival after bone marrow transplantation for leukemia. Psychosom Med 1994;56:432-9.

18. Shin HR, Ahn YO, Bae JM, Shin MH, Lee DH, Ohrr HC, Ahn DM, Jacques Ferlay, Parkin DM, Oh DK, Park JG. Cancer incidence in Korea. Cancer Res Treat 2002;34(6):405-408.

19. Kim KI, Kim JW, WON HT. SCL-90 (Revised) Manual. Seoul. 1989. Daegwang Munwha Sa.

20. Kim KI, Kim JW. Korean standerdized research (III) of SCL-90-R. Mental Health Research 1984;2:278-311. 
21. Nelson DV, Friedman LC, Baer PE, Lane M, Smith FE. Attitudes to cancer: Psychometric properties of fighting spirit and denial. J Behav Med 1989;12:341-355.

22. Tschuschke V, Hertenstein B, Arnold R, Bunjes D, Denzinger $\mathrm{R}$, Kaechele $\mathrm{H}$. Associations between coping and survival time of adult leukemia patients receiving allogenic bone marrow transplantation. Results of a prospective study. J Psychosom Res 2001;50:277-285.

23. Morris T, Pettingale K, Haybittle J. Psychological response to cancer diagnosis and disease outcome in patients with breast cancer and lymphoma. Psychooncology 1992;1:105-114.

24. Fukuzi S, Kukara A, Okama H, Kamiya M, Koike M, Nakanishi T, Imoto S, Kanakawa K, Uchitomi Y. A psychsocial group intervention for Japenese women with primary breast carcinoma. Cancer 2000;5:1026-1036.

25. Fawzy IF, Fawzy NW, Arndt LA, Pasnau RO. Critical review of psychosocial intervention in cancer care. Arch Gen Psychiatry $1995 ; 52: 100-113$. 